\title{
Development of Korean Standardized Sentences on Voice Quality Evaluation for Dysphonia
}

\author{
Seong Hee Choi \\ Department of Audiology \& Speech-Language Pathology, Research Institute of Biomimetic Sensory Control, and \\ Catholic Hearing Voice Speech Center, Daegu Catholic University, Gyeongsan, Korea
}

음성장애 환자의 음질 평가를 위한 표준문장 개발

최 성 희

대구가톨릭대학교 바이오메디대학 언어청각치료학과, 생체모방감각제어연구소, 가톨릭 청각음성언어센터

\begin{abstract}
Purpose: The purpose of this study was to develop the Korean standardized sentences to elicit various laryngeal behaviors for voice quality evaluation and to investigate the validity of new developed sentences. Methods: Phoneme and word frequencies of Korean standardized passages ('Fall', 'Walk') were analyzed and words were selected based on high- frequency words from speech corpus 'Sejong' for the purpose of each sentence. Six standardized sentences were developed: sentence included Korean all vowels, sentence begins with the $/ \mathrm{h} /$ sound, sentence consisted of all voiced sounds, sentence elicits hard glottal attack, sentence incorporated nasal sounds, sentence weighted with voiceless plosive sounds. For verifying the effect of sentence type on voice quality, acoustic measures [speaking fundamental frequency (SFF), Cepstral peak prominence (CPP), low-to-high frequency ratio ( $\mathrm{L} / \mathrm{H}$ ratio)] were measured from 20 young speakers (10 males, 10 females) with normal voice. Results: Significant main effects for gender and sentence type appeared on the measurements of SFF, CPP, and $\mathrm{V} / \mathrm{H}$ ratio. The largest amplitude of CPP and $\mathrm{L} / \mathrm{H}$ ratio was produced in all-voiced sentence and the highest SFF was also presented in voiceless plosive consonant sentence in both males and females. Conclusion: Different consonant and vowel context in a connected speech affected the voice quality as well as frequency. Newly developed sentences consisted of various vowels and consonants may be useful to observe the different laryngeal behaviors and clinical signs as the connected speech stimuli.
\end{abstract}

Key Words: Consonant, Vowel, Connected speech, Voice quality.

Received: April 2, 2018 / Revised: April 9, 2018 / Accepted: April 17, 2018

Correspondence: Seong Hee Choi, Department of Audiology \& Speech-Language Pathology, Research Institute of Biomimetic Sensory Control, and Catholic Hearing Voice Speech Center, Daegu Catholic University, 13-13 Hayang-ro, Hayang-up, Gyeongsan 38430, Korea

Tel: +82-53-850-2542 / Fax: +82-53-359-0780 / E-mail: shgrace@cu.ac.kr

\section{INTRODUCTION}

음성은 음도, 음량, 음질 및 유연성(pliability)으로 구성되어 있으며 이러한 요소들이 적절할 때 좋은 음성이 산출된다 (Sohn, 2008). 음성장애의 진단을 위해서 이러한 요소들을 적 절히 평가하는 것이 중요하며, 기기적 도구를 이용한 객관적 방 법과 청지각적 판단으로 평가하는 주관적 방법이 있다. 특히, 기기를 이용한 객관적 평가로는 다차원적인 음성의 요소들을 수치화하는 데 한계가 있기 때문에 훈련된 귀를 이용한 청지각 적 음성 평가방법이 정석으로 사용되어 왔으며, 좀 더 정확한 음성 데이터를 얻기 위해서는 기기적 평가방법과 함께 병행되 어야 한다(Kreiman et al., 1993).
장애 음성을 직접 귀로 듣고 평가하기 위해 모음발성, 문장 읽기, 자동화 구어(숫자 혹은 요일 세기 등), 회화 중 선택하여 야 하는데 최근까지 청지각적 평가를 보완하기 위해 사용되는 기기적 평가의 말과제 관련 증거기반 연구들에 의하면, 음향학 적 평가, 전기성문파형검사, 후두내시경검사들이 말과제와 구 조적 모양, 후두 위치, 성대 진동 패턴 간에 유의한 상관관계가 있음을 보고하였다. 특히, 모음의 종류, 음도 수준, 모음 대 글자 기반 문장 문맥, 발화 길이, 말속도가 성도의 모양, 발성 개시, 음절과 단어 사이 멈춤에 영향을 준 것으로 나타났다(Colton et al., 2011; Lu \& Matteson, 2014; Parsa \& Jamieson, 2001).

마찬가지로 청지각적 평가에서도 연장발성, 음도, 음량, 조음, 말속도 등의 말 특징들은 청자들이 화자의 음질을 정확히 판 
단하는 데 영향을 줄 수 있다. 말과제 중 모음 연장발성은 말과 제의 특성상 안정적이고 일관성 있게 산출하기에 용이하므로 평가자 내 평가자 간 신뢰도가 높은 장점이 있으나, 환자 음성 을 대표하기 어렵고, 장애 음성의 중증도가 실제 발화보다 낮 게 평가될 우려가 있다. 반면, 연속발화는 말속도, 운율, 방언 등 다양한 말의 특징으로 평가자 내 및 평가자 간 신뢰도가 낮 은 문제가 있지만, 일상생활의 환자 음성을 가장 잘 반영할 수 있고 특히, 모음보다는 연속발화가 환자 음성의 중증도와 높은 상관성을 보이므로 좀 더 정확한 음질을 평가할 수 있다(Choi \& Choi, 2016; Yu et al., 2017).

음질 평가를 위한 청지각적 평가 시 말과제는 주로 모음 연 장발성과 연속발화를 모두 사용하도록 권고하고 있는데, 대부 분의 국외 청지각적 평가를 위한 표준 가이드라인에 의하면, 모 음 연장발성(///와 / / / 과 자국어의 음소적 균형을 이룬 짧은 문단 읽기를 사용하고 있다.

국내 임상에서 음성 평가를 위해 사용하고 있는 말과제는 모 음과 표준문단을 사용하는 경우는 $52 \%$ 에 불과하였고, 모음만 사용하는 경우는 $17 \%$, 모음과 문장을 함께 사용하는 경우는 $10 \%$, 모음과 문단, 일상 대화를 모두 사용하는 경우가 $3 \%$ 였다. 모음의 경우도 응답자의 대부분이 모음 '아'만을 사용하였고 (98\%), 약 $70 \%$ 가 표준문단을 사용하였으며 자체 제작된 문장 이나 문단을 사용하였다(14\%)(Choi, 2013).

한국어 음소의 균형을 고려하여 제작된 국내 표준문단 중 '산책(Jeong, 1994)'은 총 7문장, '가을(Kim, 1996)'은 총 9문장 으로 구성되어 있고 문장마다 평균발화 길이가 모두 다양하여 바쁜 임상에서 모든 문장을 읽을 때 어느 정도 시간이 소요되 고, 환자 개인의 상태에 따라 문장을 모두 읽기에 어려움이 있 을 수도 있다. 이러한 점을 고려하여 최근에는 문단 내 표준문 단 중 일부 문장을 사용하기도 하지만 국내외 연구자마다 일관 성이 없고, 위치에 따라 서로 다른 음질의 차이를 보이는 것으 로 보고되었다(Kang \& Ku, 2015; Lee et al., 2017; Lowell et al., 2012).

장애 음성의 청지각적 판단을 위해 임상에서 가장 널리 사용 하는 GRBAS 척도의 음성표본은 단순모음발성(/아/, /이/, /우/, /에/, /오/)과 연속발화이다. 최근에 장애 음성의 청지각적 판단 을 평가하고 문서화하기 위하여 2002년 미국 언어청각임상협회 (American Speech-Language Hearing Association)에서 표준 적 청지각적 평정 도구로서 개발된 consensus auditory-perceptual evaluation of voice (CAPE-V)는 GRBAS 척도와는 달리 복잡하고 다양한 음성의 다차원적 속성을 평가하기 위하 여 음질(quality) 외에 음도(pitch), 음량(loudness), 공명(resonance) 등 다양한 항목들을 포함한다. CAPE-V 척도에서는 모 음(///와 / / /)과 환자의 목소리 문제에 대해 최소 20 초간 이야
기하는 연속발화 이외에 다양한 후두 움직임과 임상 특징을 이끌어 내기 위해 6 개의 짧은 문장이 개발되어 사용되고 있다 (Kempster et al., 2009; Zraick et al., 2011). 최근 스페인과 이탈 리아에서도 자국어에 맞는 표준문장을 개발하여 임상에 적용 하여 사용하고 있다(Mozzanica et al., 2013; Núñez-Batalla et al., 2015).

CAPE-V 척도의 개발 목적은 음성 문제의 청지각적 속성들 의 중증도(severity)를 기술하는 것이 주요 목적이지만, 이외에 음성 문제의 원인이 될 수 있는 해부학적, 생리학적 근거에 대 한 가설을 세우고 추가적인 검사에 대한 수요를 평가하는 것이 며(Kempster et al., 2009), 이러한 평가결과들은 추후 음성 중 재의 목표와 방향을 설정하는 데 도움을 줄 수 있다.

따라서 음성 평가 시 음성 문제의 중증도 외에 발성에 영향 을 미칠 수 있는 후두의 다양한 해부학적 구조와 생리학적 기 능들을 예측하고 파악하기 위해서는 단순모음발성만으로는 제 한적이며, 음성 평가 시 서로 다른 음소 문맥으로 구성된 말과 제를 사용하여 평가하는 것이 필요하다.

이러한 관점에서 국내에서도 음성 평가를 위한 문장 수준의 다양한 말과제의 필요성이 대두되는 바 본 연구는 한국 표준 문단의 음소 빈도를 분석하고, 성인 자유발화 자료를 기초로 한 한국인 '세종' 구어 말뭉치를 기초로 하여 임상 현장에서 다 양한 후두 움직임과 임상적 특성을 반영할 수 있는 서로 다른 음소적 문맥을 가진 표준문장을 개발하고 타당도를 검토하고 자 한다. 또한 타당도 검증을 위해 연속발화의 청지각적 음질을 객관적으로 측정할 수 있고, 연속발화의 청지각적 평정과 가장 상관성이 높다고 알려진 음향학적 측정치인 캡스트럼 분석치 (Yu et al., 2017)와 연속발화의 음도를 측정할 수 있는 평균발 화 기본주파수를 측정함으로써 음도, 강도, 음질과 같은 다양 한 음성 특성을 평가할 수 있는지 살펴보고자 한다.

\section{MATERIALS AND METHODS}

\section{표준문단과 구어 말뭉치 분석}

표준문장의 어휘를 선정하기 위하여 표준문단('가을, '산책') 의 음소 및 단어 빈도를 조사하였고, 한국인 성인 자유발화의 회화체에서 나타난 단어의 빈도를 조사하였다.

\section{표준문단의 음소와 단어 빈도 분석}

표준문단은 서울 표준말을 사용하는 연구자에 의해 방음실에 서 녹음되었다. 낭독은 단일 지향성 녹음용 마이크(D7 Vocal, AKG, Vienna, Austria)를 사용하여 최대한 자연스러운 발화 와 말속도로 표준문단인 '가을(Kim, 1996)'과 '산책(Jeong, 1994)' 문단을 읽었으며, 녹음 시간은 '가을' 문단은 총 1 분 16초, 
'산책' 문단은 총 1 분 27 초였다.

음소 및 단어 출현 빈도를 조사하기 위하여 발음 나는 대로 전사한 후 빈도 정보를 추출하였다. '가을' 문단은 총 명사, 대명 사, 관형사/형용사, 부사, 조사, 감탄사, 수사, 의존명사 등을 포 함한 총 194개 단어를 분석하였으며(Appendix 1), '산책' 문단 은 총 124개를 분석대상으로 하였다(Appendix 2).

\section{한국어 회화체 단어 빈도 분석}

한국 성인 자유발화에서 자주 사용되는 단어의 빈도를 조사 하기 위하여 1992 2005년 사이에 직접 녹음을 통해 수집된 한 국어 '세종 구어 말뭉치(Seo, 2015)'에서 표준문장별로 필요로 하는 단어의 빈도를 조사하였고, 문장별로 50 60개씩 고빈도 어휘목록을 선정하였다(Appendix 3 7).

\section{표준문장 개발}

본 연구의 개발문항을 제작하기 위해서 먼저 다음과 같은 사 항을 고려하였다. 첫째, 각 표준문장의 목적이 분명히 실현될 수 있는 검사어 선정이 중요하기 때문에, 각 표준문장의 목적 에 최대한 부합되는 음소와 단어가 포함되도록 하였다. 둘째, 임상에서 표준문단이 약 $70 \%$ 이상 사용되고 있는 점을 감안 할 때(Choi, 2013), 기존에 널리 사용되고 있는 표준문단의 측 정치들과 비교를 용이하게 하기 위해서 표준문단의 음소 빈도 와 음소적 분포의 균형이 이루어지도록 하였다. 셋째, 음성 분 석을 위한 표준문장은 한국어 회화체에서 어음 빈도를 고려하 여 음소적 분포 및 음소 출현 빈도와 균형을 맞추고, 단어의 상 용성과 친숙성을 고려하는 것이 바람직하므로 '구어' 즉, 음성 으로 실현된 말의 음소적 출현 빈도와 한국어 구어 단어 빈도 를 고려하여 말할 때 자주 사용되는 단어를 포함하도록 하였 다. 넷째, 음성장애 환자의 연속발화 시 호흡의 영향을 최소화 하기 위하여 문장의 음절 수를 고려하였다. 최근 음성장애 환 자의 연속발화 시 호흡의 연구에 의하면, 정상 성인은 한 호흡 단락당 음절 개수가 17.05개였으나, 20 49세 여성 양성 성대병 변 환자군은 15.69 개, 50 세 이상의 여성 양성 성대병변 환자군 은 13.60 개였으므로, 발화 시 호흡의 영향을 고려하여 한 문장 당 20음절이 넘지 않도록 하였다(Pyo et al., 2014). 또한 환자가 읽기에 어려움이 있을 경우 읽어 주고 따라 말하도록 해야 하 므로, 단기기억의 차이를 최소화하기 위하여 문장의 길이를 적 절하게 구성하였다.

\section{표준문장 작성과 선정}

1 차 예비문장표 개발

선정된 어휘목록을 토대로 문장 길이 및 문장 내용을 고려
하여 6 개의 항목에 부합한 예비 표준문장을 각 항목당 10 개씩 총 60 개 예비 문장을 제작하였다. 각 항목마다 문장 길이는 5 7 개의 낱말이 포함되도록 문장 길이를 비슷하게 조절하였다.

\section{표준문장 선정}

국어학자에게 자문을 얻어 1 차 예비 문장 목록을 제작한 후 음성장애 전공 교수 및 관련 전문인(음성학자, 청각학자) 5 인과 음성장애 전공 석박사 과정 대학원생 5 인에게 5 점 척도로 일상 생활의 문장으로서 타당하고 각 항목의 목적이 잘 드러나는 문장인지 내용 타당도를 조사하였으며 가장 점수가 높은 예비 문장을 표준문장으로 선정하였다(Appendix 8).

\section{타당도}

본 연구는 인간 대상연구로서 대구가톨릭대학교에서 IRB 승 인(CUIRB-2014-0006)을 받아 이루어졌으며 대상자는 자발적 인 참여로 이루어졌다. 선정된 표준문장이 연속발화로서 개발 된 최종문장표는 소음이 차단된 방음실에서 20 29세(평균: $24.6 \pm 7$ )의 정상 성인 20명(남 10 , 여 10)을 대상으로 자연스러운 발화와 말속도로 편안한 음도와 음량에서 각 문장을 읽도록 하 였다. 각 문장은 무작위 순서로 배치한 후 녹음 전 2번 정도 연 습을 거친 후 적정한 말속도를 유지하면서 읽도록 하였다. 녹음 은 Computerized Speech Lab (CSL) 프로그램(Model 4300B, Pentax Medical, Lincoln Park, NJ, USA)을 사용하여 44,100 $\mathrm{Hz}$ 에서 표본추출율에서 $16 \mathrm{bit}$ 로 양자화하였다. 음향학적 특 성을 통해 문장 효과를 살펴보기 위하여 CSL의 real-time pitch를 이용하여 각 표준문장의 기본주파수를 측정하였으며, 표준문장의 스펙트럼과 캡스트럼 측정을 위해 Analysis of Dysphonia in Speech and Voice (ADSV ${ }^{\mathrm{TM}}$; Model 5109, Pentax Medical, Montvale, NJ, USA)를 이용하여 각 문장의 시작 부분에서 끝부분까지 자동음성 부분 검출 방식으로 각 문장의 Cepstral peak prominence (CPP), low-to-high frequency ratio (L/H ratio)를 측정하였다.

\section{통계 분석}

수집된 결과는 SPSS version 20.0 (IBM Corp., Armonk, NY, USA) 소프트웨어를 이용하여 분석하였다. 본 연구에서는 성별(개인 간 변수)과 문장 유형(개인 내 변수)이 음향학적 측정 치인 종속변수에 미치는 영향을 확인하기 위해 혼합 이원배치 분산분석(mixed two-way ANOVA)을 실시하였고, 통계적으 로 유의수준은 0.05 수준에서 검정하였다. 개체 간 반복 측정 에 대한 통계 검정은 Mauchly의 구형성 가정에 의해 구형성이 가정된 경우는 구형성 가정값을 사용하였고, 구형성 가정을 만 족하지 않은 경우는 Greenhouse-Geisser로 수정된 자유도와 
$\mathrm{F}$ 값을 보고하였다. 문장 유형 효과가 있는 경우, 문장 유형 간 차이를 살펴보기 위해 대응별 비교를 실시하였다.

\section{RESULTS}

\section{표준문단의 자음과 모음 빈도}

'가을' 문단의 경우, 총 음소 수는 840개였고, 이 중에서 자음 은 총 468개(56\%), 모음은 총 372개(44\%)로 자음의 빈도 비율 이 더 높았다. '산책' 문단도 총 음소 수는 795개였고, 이 중에서 자음은 총 471개(59\%), 모음은 총 324개(41\%)로 자음이 더 많 았다.

\section{표준문단의 모음 빈도와 음소적 분포}

'가을 문단의 경우, 한국어 단모음 7 개가 모두 출현하였다. 빈 도별로 볼 때. 단모음의 출현율이 이중모음보다 높았다. 단모음 은 / / / 가 26\%(97/372)로 가장 많았고, / / / 16\%(61/372) > /// $13 \%(47 / 372)>/$ ㄴ/ / 11\%(40/372) > / // 9\%(33/372) > / / / / $8 \%(30 / 372)>/ T / 7 \%(26 / 372)$ 순으로 $/ / /, / / / / / /$ 가 전체 모 음의 55\%를 차지하였다(Figure 1). 이중모음은 /月/ 4\%(15/372) 로 가장 많았고, / / / / 2\%(7/372), /과/ 1\%(5/372), /ㅖ/ / 1\% (5/372), /교/ 0.5\%(2/372), / / / 0.3\%(1/372) 순으로 총 6개의 이 중모음이 포함되어 있었다.

'산책' 문단도 '가을' 문단과 마찬가지로, 모든 한국어 단모음 7개가 출현하였으며, 모음 빈도수는 / / /가 36\%(117/324)로 가장 높은 비율을 나타내었고, / / / 22\%(72/324) > / / / 13\%(42/324) > / ㄷ/ 10\%(34/324) > / / / 9\%(30/324) > / T/ 7\%(23/324) > / - / 4\%(13/324) 순이었다(Figure 2). 이중모음은 총 4개로 / / / 7\% (22/324)가 가장 많았고, /月/ 4\%(14/324) > /기/ 0.6\%(2/324),

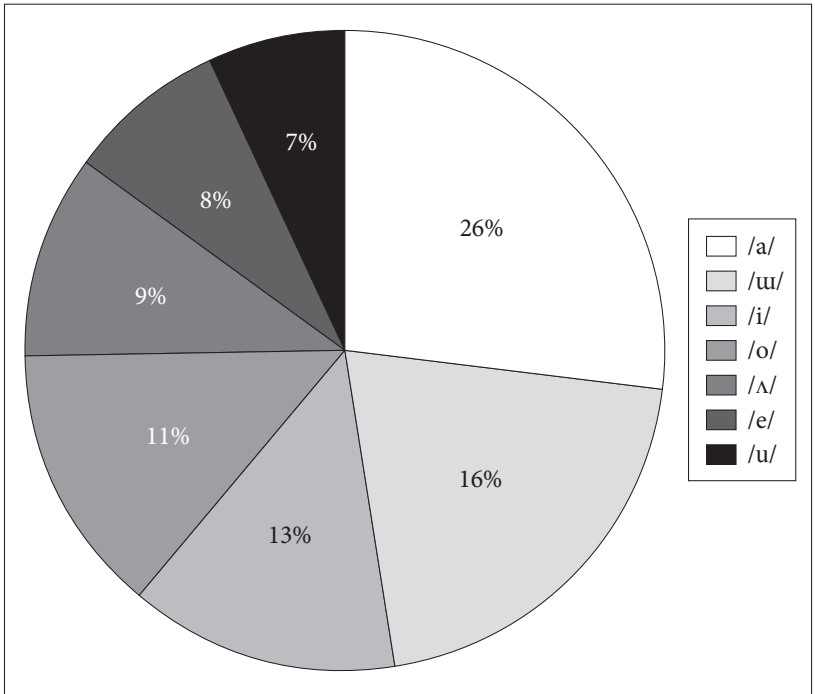

Figure 1. Phonetic distribution of single vowels in 'Fall' passage.
// / 0.3\%(1/324) 순이었다.

표준문단의 자음 빈도와 음소적 분포

'가을' 문단은 한국어의 모든 자음을 포함하였으며, 자음별 로는 /리 음소가 18\%(83/468)로 가장 많은 비율을 나타내었 고, /ㄴ/ 16\%(73/468) > /ᄃ/ 15\%(70/468) > /ᄀ/ 11\%(52/468) > /ㅁ/ 7\%(33/468) > / ㅅ/ 7\%(32/468) > /ᄒ/ 6\%(25/468) > / ㅈ/ $5 \%(22 / 468)>/$ ㅊ/ $1 \%(7 / 468)>/$ 표 $1 \%(6 / 468)>/$ E $/ 1 \%$ (4/468) 순이었다.

‘산책' 문단도 모든 한국어 자음을 포함하였으며, 이 중에서 /ㄴ/이 23\%(106/471)로 가장 높은 빈도를 나타내었고, /리 17\% $(80 / 471)>/ \neg / 12 \%(56 / 471)>/$ ᄃ/ 8\%(37/471) > /ㅁ/ 7\% $(34 / 471)>/$ ㅂ $/ 7 \%(25 / 471)>/$ ㅈ/ $5 \%(23 / 371)>/ 0 / 3 \%$ $(15 / 471)>/$ 匹 $/ 3 \%(13 / 471)>/$ / $/ 3 \%(12 / 471)>/$ ᄒ $/ 3 \%$

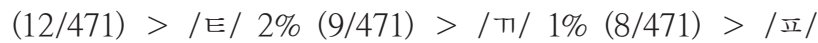

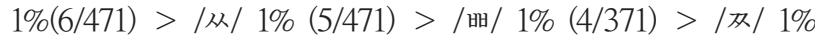
(4/471) 순이었다(Figure 3).

음절 내 위치별로 볼 때, '가을 문단에서는 총 468 개 자음 중 초성의 위치가 가능한 자음(/ᄀᄀ/, / ㄲ/, /ㄴ/, /ㄷ/, /匹ᄄ, /ㄹ/, /ㅁ/, /ㅂ/, /삐/, /ㅅ/, /ㅆ/, /O/, /ㅈ/, /ㅉ/, /ㅊ/, /ㅋ/, /E/, /피/, /ㅎ/) 총 19 개의 초성 빈도수는 350 개(75\%)였으며, 종성의 위치가 가능 한 자음(/ᄀ/, /ㄴ/, /ㄷ/, /ㄹ/, /ㅁ/, /ㅂ/, /O/) 총 7개의 종성 빈도 수는 118 개(25\%)로 자음의 3/4이 초성에서 사용되었다(Figure 4). 마찬가지로, '산책' 문단에서는 총 471 개 자음 중 초성 빈도 수는 293개(62\%)였고, 종성 빈도수는 178개(38\%)로 초성 빈도 수가 종성 빈도수에 비해 높은 비율을 보였으며 전체 음소 위 치에서 초성이 $2 / 3$ 를 차지하였다(Figure 5).

조음방법별 출현 빈도를 살펴본 결과, '가을' 문단은 파열음

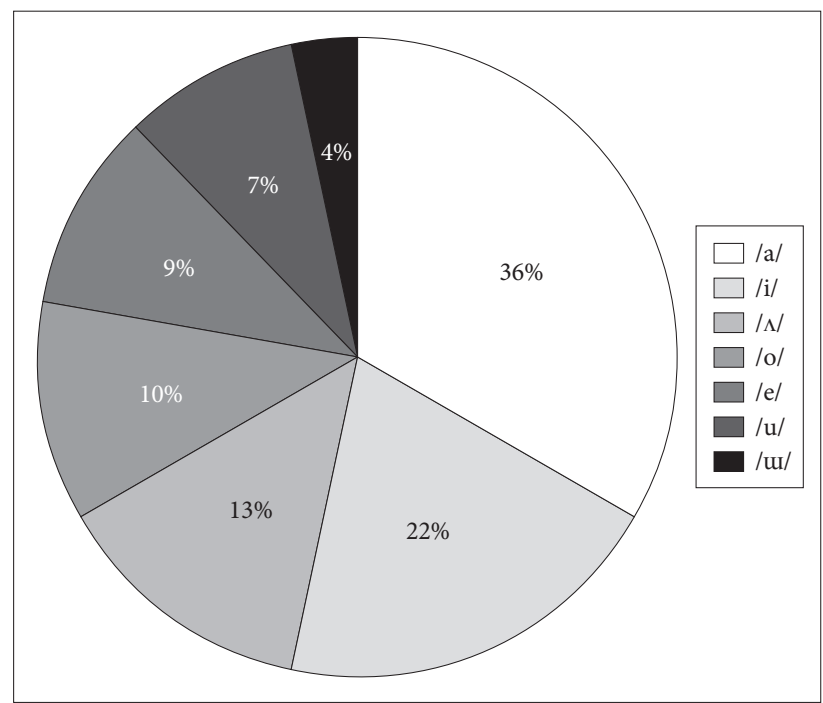

Figure 2. Phonetic distribution of single vowels in 'Walk' passage. 
$37 \%(173 / 468)$ 가 가장 많았고, 비음 25\%(119/468) > 마찰음 $13 \%(62 / 468)>$ 유음 18\%(83/468) > 파찰음 7\%(31/468) 순이 었다. 이와 마찬가지로 '산책' 문단은 파열음 $34 \%(161 / 471)$ 가 가 장 많이 출현하였고, 비음 $33 \%(155 / 471)>$ 마찰음 10\%(47/471) > 파찰음 8\%(39/471) > 유음 17\%(80/471) 순으로 나타나 두 문 단 모두 파열음을 가장 많이 포함하였다(Figure 6).

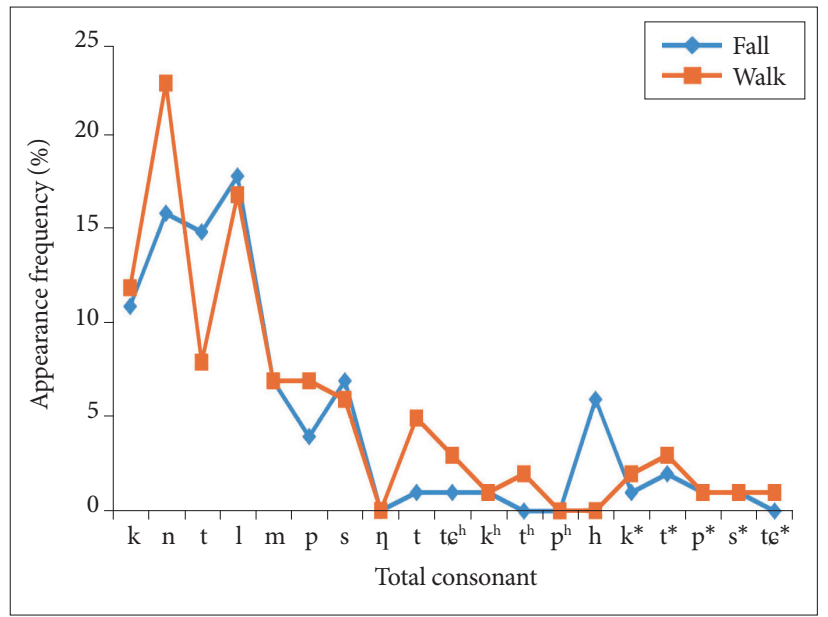

Figure 3. Total consonant frequency in 'Fall' \& 'Walk' standardized passages. *Fortis. ${ }^{\text {h: }}$ aspirated.

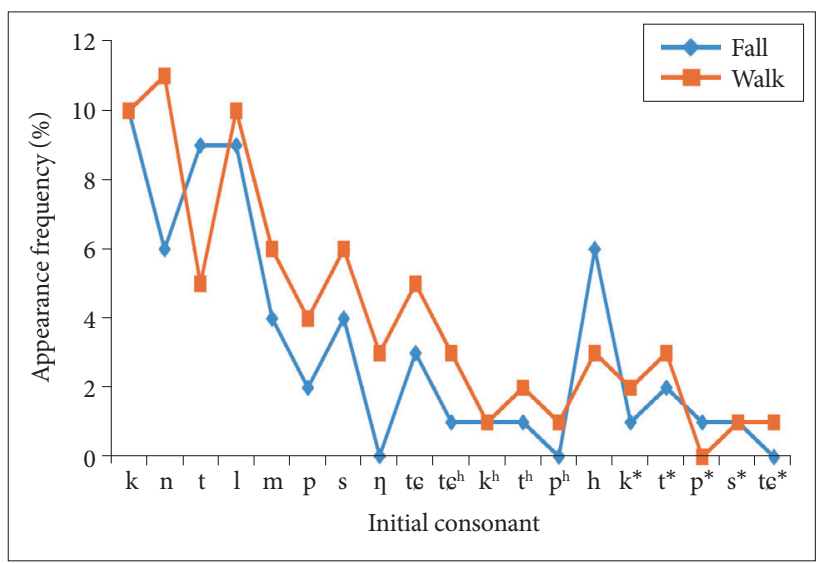

Figure 4. Consonant frequency in initial sound in 'Fall' \& 'Walk' standardized passages. *Fortis. " : aspirated.

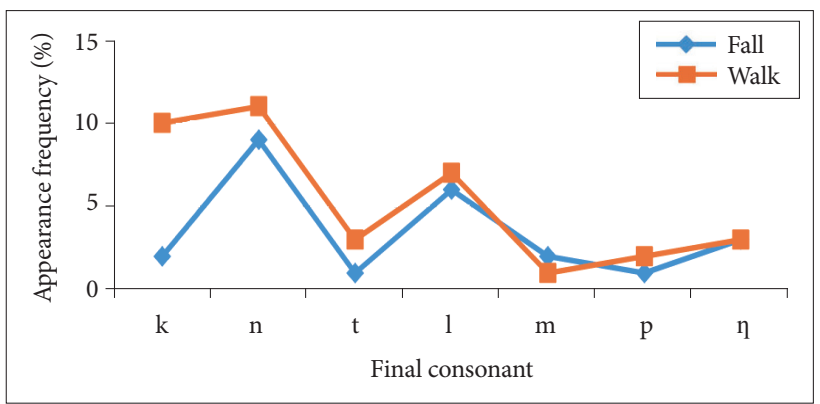

Figure 5. Consonant frequency in final sound in 'Fall' \& 'Walk' standardized passages.
조음 위치별로는 '가을' 문단은 치경음 58\%(272/468)가 압도 적으로 가장 높은 빈도를 보였으며, 연구개음 $16 \%(75 / 468)>$ 양 순음 13\%(59/468) > 경구개음 7\%(31/468) > 성문음 6\%(25/468)

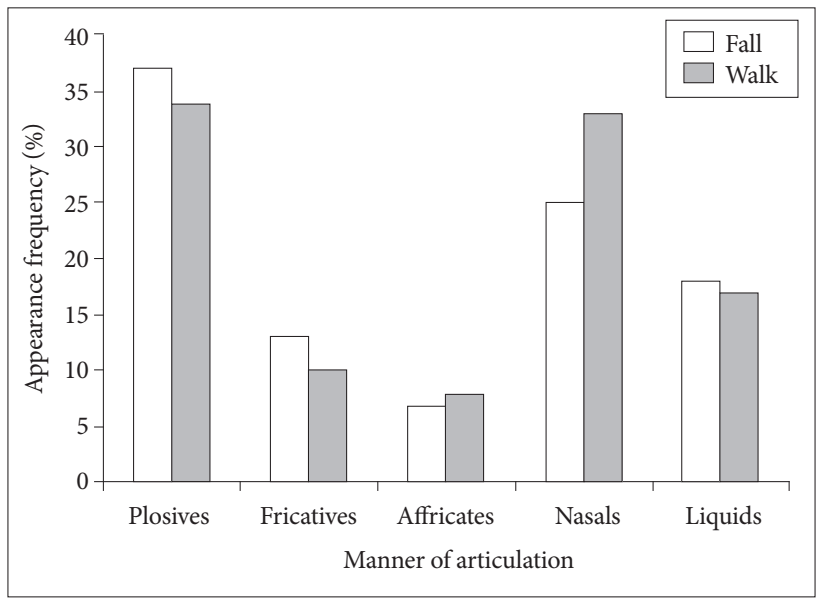

Figure 6. Consonant frequency according to manner of articulation in 'Fall' \& 'Walk' standardized passages.

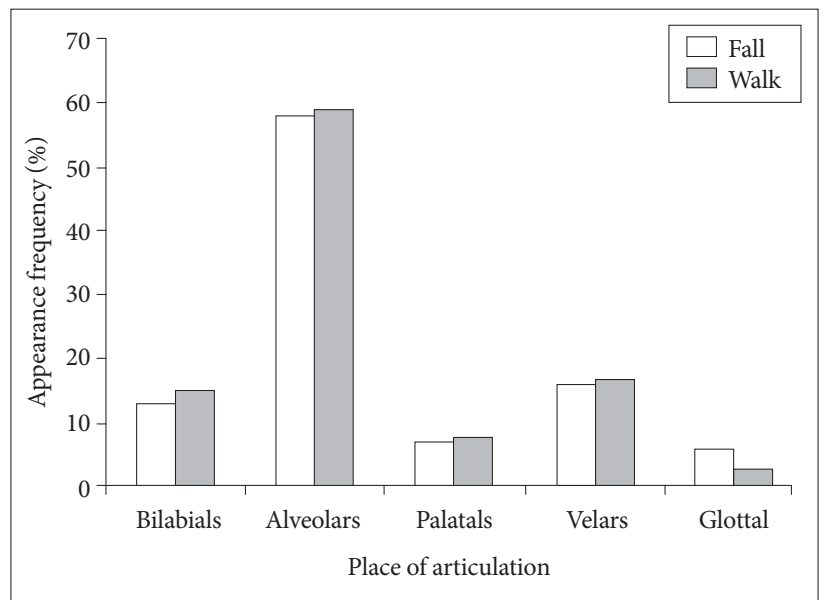

Figure 7. Consonant frequency according to place of articulation in 'Fall' \& 'Walk' standardized passages.

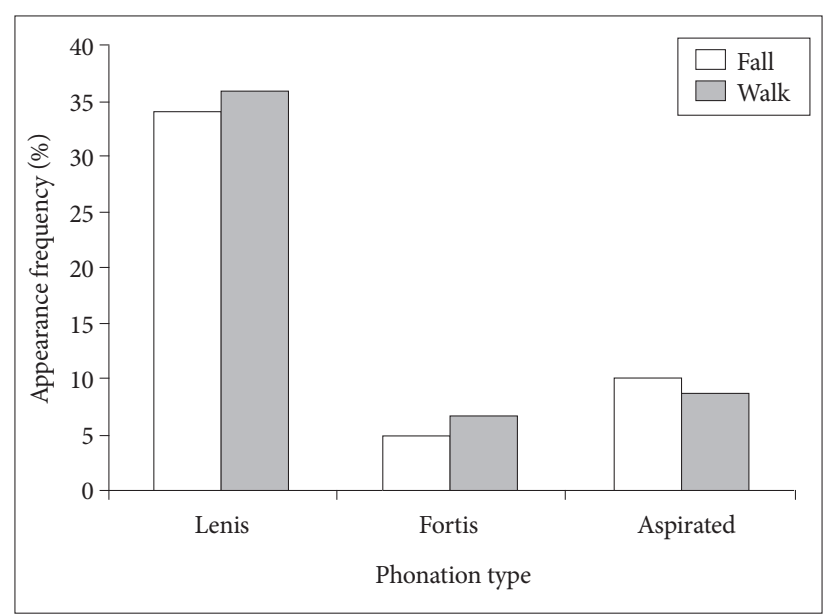

Figure 8. Consonant frequency based on phonation type in 'Fall' \& 'Walk' standardized passages. 
순이었다. '산책' 문단도 치경음 59\%(280/471)의 빈도수가 가장 높았으며, 연구개음 $17 \%(82 / 471)>$ 양순음 $15 \%(69 / 471)>$ 경구 개음 8\%(39/471) > 성문음 3\%(12/471) 순이었다(Figure 7).

발성 유형별로는 '가을' 문단은 평음 34\%(161/468)로 압도적으 로 높은 빈도수를 보였으며, 격음 10\%(48/468), 경음 5\%(25/450) 로 경음이 가장 낮은 빈도를 보였다. 이와 마찬가지로 '산책' 문 단은 평음 36\%(171/471)로 가장 높은 빈도를 나타냈으며, 격음 9\%(42/471), 경음 7\%(34/471) 순이었다(Figure 8).

\section{한국어 회화체 단어 빈도 분석}

한국어 단모음 7개(Shin \& Cha, 2003)가 모두 산출될 수 있 는 문장을 개발하기 위해서 표준문단의 자음 빈도 및 분포와 성인 자유발화의 고빈도 단어와 비교하여 조절하였다.

부드러운 발성을 위한 /히으로 시작하는 문장을 개발하기 위해 세종 말뭉치 가운데 성인 자유발화에서 '흐으로 시작하는 고빈도 단어와 모든 유성음으로 된 문장을 제작하기 위하여 유성음으로 된 고빈도 단어를 각각 선정하였다(Appendix 3, 4). 또한 모음으로 시작하는 단어는 강한 성대접촉을 유도하기 에 용이하므로 세종 말뭉치에서 모음으로 시작하는 고빈도 단 어를 조사하였으며 Appendix 5에 제시하였다.

비음이 포함된 문장을 개발하기 위해서 비음이 포함된 고빈 도 단어 목록을 선정하였으며(Appendix 6), 무성파열음이 강 조된 문장을 개발하기 위해 무성파열음이 포함된 고빈도 단어 를 조사하여 Appendix 7에 제시하였다.

Table 1. SFF measures among different sentence type

\begin{tabular}{llc}
\hline \multicolumn{1}{c}{ Gender } & SFF $(\mathrm{Hz})$ & $p$ \\
\hline With all vowels & $120.50( \pm 12.43)$ & $0.000^{* *}$ \\
M & $213.43( \pm 8.34)$ & \\
F & & \\
With the /h/ & $131.45( \pm 13.42)$ & $0.000^{* *}$ \\
M & $227.64( \pm 13.25)$ & \\
F & & \\
All voiced & $119.09( \pm 9.65)$ & $0.000^{* *}$ \\
M & $210.51( \pm 10.07)$ & \\
F & & \\
Hard glottal attack & $131.92( \pm 13.96)$ & $0.000^{* *}$ \\
M & $217.46( \pm 16.90)$ & \\
F & & \\
With nasal sounds & $121.74( \pm 9.40)$ & $0.000^{* *}$ \\
M & $215.47( \pm 11.44)$ & \\
F & & $0.000^{* *}$ \\
With voiceless plosive sounds & \\
M & $141.17( \pm 10.79)$ \\
F & $236.87( \pm 9.93)$ & \\
\hline
\end{tabular}

${ }^{* *} p<0.01$. SFF: speaking fundamental frequency

\section{개발된 표준문장}

개발된 표준문장은 총 6 개로 첫째, 한국어 모든 단모음이 포 함된 문장, 둘째, ‘’으로 시작하는 문장, 셋째, 모두 유성음으 로 된 문장, 넷째, 강한 성대접촉을 유도하는 문장, 다섯째, 비 음이 포함된 문장, 여섯째, 유성파열음이 가중된 문장이며 각 표준문장은 Appendix 8과 같다.

문장 간 음향학적 특성의 차이를 보기 위하여 발화 기본주파 수(speaking fundamental frequency, SFF)를 측정한 결과는 Table 1과 같다. 각 문장 간 SFF는 모든 단모음이 포함된 문장 은 남성 $120.50( \pm 12.43) \mathrm{Hz}$, 여성 213.43( \pm 8.34$) \mathrm{Hz}$, /히으로 시작하는 문장은 남성 $131.45( \pm 13.42) \mathrm{Hz}$, 여성 227.64( \pm 13.25 $\mathrm{Hz}$, 모두 유성음으로 된 문장은 남성 $119.09( \pm 9.65) \mathrm{Hz}$, 여성 $210.51( \pm 10.07) \mathrm{Hz}$, 강한 성대접촉으로 시작하는 문장은 남성 $131.92( \pm 13.96) \mathrm{Hz}$, 여성 $217.46( \pm 16.90 \mathrm{~Hz}$, 비음이 포함된 문 장은 남성 $121.74( \pm 9.40) \mathrm{Hz}$, 여성 215.47( \pm 11.44$) \mathrm{Hz}$ 였으며, 무 성파열음이 가중된 문장은 남성 $141.17( \pm 10.79) \mathrm{Hz}$, 여성 236.87 $( \pm$ 9.93) $\mathrm{Hz}$ 로 무성파열음이 가중된 문장이 가장 높았으며, 모 두 유성음으로 된 문장이 가장 낮았다(Figure 9). 혼합 이원배 치분산분석(mixed two-way ANOVA) 결과, 성별과 문장 유 형 간에는 상호작용은 유의미하지 않았으며 $[\mathrm{F}(5,90)=1.713, p=$ $0.140]$, 성별 간 $[\mathrm{F}(1,18)=390.723, p=0.000]$, 문장 유형 간 $[\mathrm{F}(5,90)=75.176, p=0.000]$ 통계적으로 유의미한 차이가 나 타났다. 대응별 비교결과, 단모음이 모두 포함된 문장은 /히으 로 시작하는 문장 $(p=0.000)$, 강한 성대접촉을 유도하는 문장

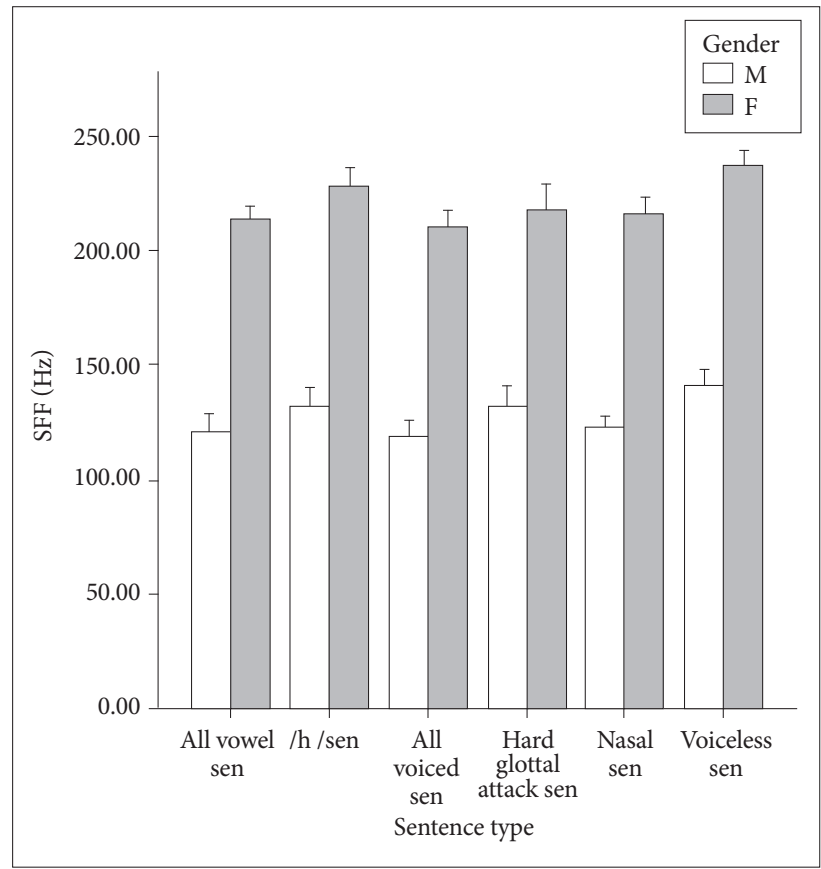

Figure 9. SFF according to gender and sentence type. SFF: speaking fundamental frequency, sen: sentance. 
( $p=0.003)$, 무성파열음이 가중된 문장 $(p=0.000)$ 과 유의한 차이를 보였다. /히으로 시작하는 문장은 모든 단모음이 포함된 문장 $(p=0.000)$, 모두 유성음으로 된 문장 $(p=0.000)$, 강한 성 대접촉을 유도하는 문장 $(p=0.005)$, 비음이 포함된 문장 $(p=$ $0.000)$, 무성파열음이 가중된 문장 $(p=0.000)$ 과 유의한 차이 를 보였다. 모두 유성음으로 된 문장은 /히으로 시작하는 문장 ( $p=0.000)$, 강한 성대접촉을 유도하는 문장 $(p=0.000)$, 비음 이 포함된 문장 $(p=0.003)$, 무성파열음이 가중된 문장 $(p=$ 0.000)과 차이를 보였으며, 강한 성대접촉을 유도하는 문장은 모든 단모음이 포함된 문장 $(p=0.003), /$ 히으로 시작하는 문 장 $(p=0.005)$, 모두 유성음으로 된 문장 $(p=0.000)$, 비음이 포 함된 문장 $(p=0.005)$, 무성파열음이 가중된 문장과 차이를 보 였고 $(p=0.000)$, 비음이 포함된 문장 $(p=0.005)$, 무성파열음 이 가중된 문장과 차이를 보였고 $(p=0.000)$, 무성파열음이 가 중된 문장은 모든 단모음이 포함된 문장 $(p=0.000), /$ 흐으로 시 작되는 문장 $(p=0.000)$, 모두 유성음으로 된 문장 $(p=0.000)$, 강한 성대접촉을 유도하는 문장 $(p=0.000)$, 비음이 포함된 문 장 $(p=0.000)$ 과 발화 기본주파수에서 차이를 보였다.

한편, $\mathrm{CPP}$ 값은 모든 단모음이 포함된 문장은 $6.43( \pm 1.40)$ $\mathrm{dB}, /$ 히으로 시작하는 문장은 $6.86( \pm 1.66) \mathrm{dB}$, 모두 유성음 으로 된 문장은 $7.70( \pm 1.10) \mathrm{dB}$, 강한 성대접촉으로 시작하는 문장은 6.46( \pm 1.23$) \mathrm{dB}$, 비음이 포함된 문장은 6.88( \pm 1.32$)$ $\mathrm{dB}$ 이었으며, 무성파열음이 가중된 문장은 $5.88( \pm 1.30) \mathrm{dB}$ 로 모두 유성음으로 된 문장이 가장 높았고, /히으로 시작하는 문 장, 비음이 포함된 문장 순으로 높았고, 무성파열음이 가중된 문장이 가장 낮게 나타났다(Table 2, Figure 10). 혼합 이원배치 분산분석(mixed two-way ANOVA) 결과, 성별과 문장 유형 간에는 상호작용은 유의미하지 않았으며 $[\mathrm{F}(5,90)=0.202, p=$ $0.960]$, 성별 간 $[\mathrm{F}(1,18)=1.920, p=0.183]$ 에는 유의한 차이가 나타나지 않았으나, 문장 유형 간 $[\mathrm{F}(5,90)=15.607, p=0.000]$ 통계적으로 유의미한 차이가 나타났다. 대응별 비교결과, 단모 음이 모두 포함된 문장은 ‘ㅎ으로 시작하는 문장 $(p=0.006)$, 모두 유성음으로 된 문장 $(p=0.000)$, 비음이 포함된 문장과 차 이를 보였고 $(p=0.000), /$ 히으로 시작하는 문장은 유성음으로 시작하는 문장 $(p=0.013)$, 강한 성대접촉을 유도하는 문장 $(p=$ $0.025)$, 무성파열음이 가중된 문장 $(p=0.000)$ 과 유의한 차이를 보였다. 모두 유성음으로 된 문장은 모든 단모음이 포함된 문장 $(p=0.000), /$ 히으로 시작하는 문장 $(p=0.013)$, 강한 성대접촉 을 유도하는 문장 $(p=0.000)$, 무성파열음이 가중된 문장 $(p=$ $0.000)$ 과 차이를 보였다. 강한 성대접촉을 유도하는 문장은 /히으로 시작하는 문장 $(p=0.025)$, 모두 유성음으로 된 문장 $(p=0.000)$, 비음이 포함된 문장 $(p=0.003)$, 무성파열음이 가 중된 문장 $(p=0.003)$ 과 유의한 차이를 보였다. 비음이 포함된
문장은 모든 단모음이 포함된 문장 $(p=0.000)$, 강한 성대접촉을 유도하는 문장 $(p=0.003)$, 무성파열음이 가중된 문장 $(p=0.000)$ 과 유의한 차이를 보였고, 무성파열음이 가중된 문장은 /히으 로 시작하는 문장 $(p=0.000)$, 모두 유성음으로 된 문장 $(p=$ $0.000)$, 강한 성대접촉으로 시작하는 문장 $(p=0.000)$, 비음으로 된 문장 $(p=0.000)$ 과 유의한 차이를 보였다.

Table 2. CPP measures among different sentence type

\begin{tabular}{llc}
\hline \multicolumn{1}{c}{ Gender } & CPP $(\mathrm{dB})$ & $p$ \\
\hline With all vowels & & \\
M & $6.99( \pm 1.64)$ & 0.209 \\
F & $6.19( \pm 1.03)$ & \\
With the $/ \mathrm{h} /$ & & \\
M & $7.95( \pm 1.67)$ & $0.022^{*}$ \\
F & $6.36( \pm 1.11)$ & \\
All voiced & \\
M & $8.03( \pm 1.34)$ & 0.411 \\
F & $7.65( \pm 0.64)$ & \\
Hard glottal attack & \\
M & $6.62( \pm 1.59)$ & 0.106 \\
F & $6.14( \pm 0.83)$ & \\
With nasal sounds & & \\
M & $7.65( \pm 1.42)$ & $0.030^{*}$ \\
F & $6.42( \pm 0.67)$ & \\
With voiceless plosive sounds & & \\
M & $6.63( \pm 1.36)$ & 0.265 \\
F & $5.42( \pm 0.83)$ & \\
\hline
\end{tabular}

${ }^{*} p<0.05$. CPP: Cepstral peak prominence

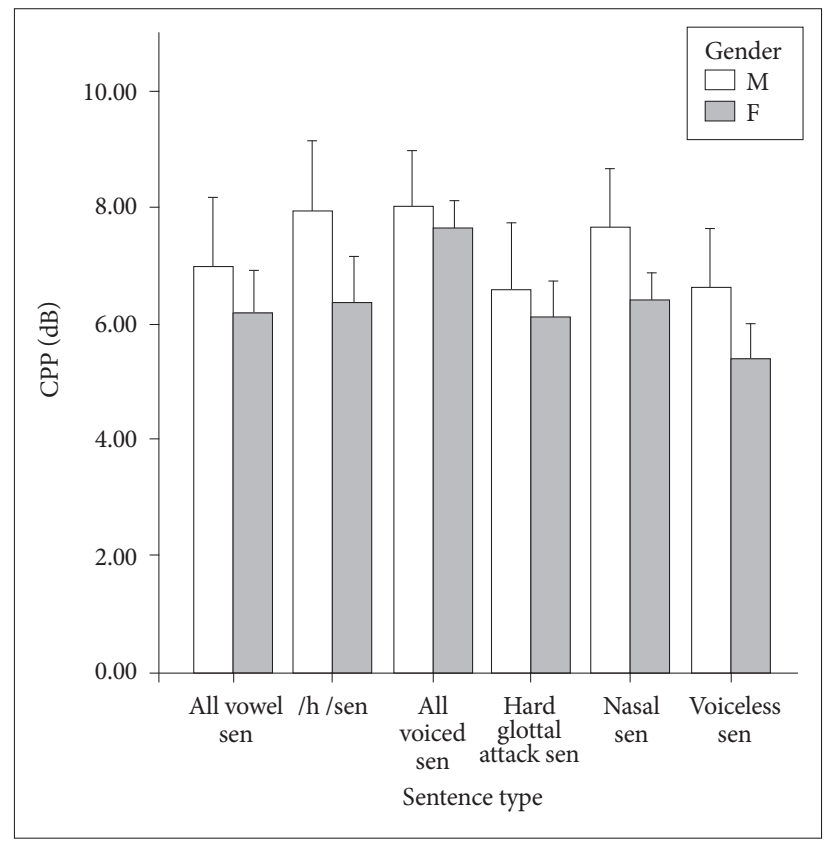

Figure 10. Comparison of CPP measures according to gender and sentence type. CPP: Cepstral peak prominence, sen: sentence. 
저주파수대고주파수비(L/H ratio)는 모든 단모음이 포함된 문장은 31.13( \pm 2.52$) \mathrm{dB}, / \mathrm{h}$ 로 시작하는 문장은 $29.19( \pm 0.60)$ $\mathrm{dB}$, 모두 유성음으로 된 문장은 33.25( \pm 2.55$) \mathrm{dB}$, 강한 성대 접촉으로 시작하는 문장은 $27.59( \pm 2.35) \mathrm{dB}$, 비음이 포함된 문장은 32.74( \pm 1.72$) \mathrm{dB}$ 이었으며, 무성파열음이 가중된 문장 은 28.24( \pm 1.62$) \mathrm{dB}$ 로 모두 유성음으로 된 문장이 가장 높았

Table 3. L/H ratio measures among different sentence type

\begin{tabular}{llc}
\hline \multicolumn{1}{c}{ Gender } & L/H ratio $(\mathrm{dB})$ & $p$ \\
\hline With all vowels & \\
$\quad$ M & $31.80( \pm 2.66)$ & 0.250 \\
F & $30.47( \pm 2.32)$ & \\
With the /h/ & \\
$\quad$ M & $30.00( \pm 0.47)$ & $0.019^{*}$ \\
F & $28.38( \pm 1.93)$ & \\
All voiced & \\
$\quad$ M & $34.05( \pm 1.34)$ & 0.162 \\
F & $32.44( \pm 2.54)$ & \\
Hard glottal attack & \\
M & $28.70( \pm 1.42)$ & 0.053 \\
F & $26.48( \pm 2.64)$ & \\
With nasal sounds & & \\
M & $32.72( \pm 1.68)$ & 0.693 \\
F & $32.77( \pm 1.84)$ & \\
With voiceless plosive sounds & \\
M & $28.50( \pm 1.81)$ & 0.480 \\
F & $27.97( \pm 1.45)$ & \\
\hline
\end{tabular}

${ }^{*} p<0.05 . \mathrm{L} / \mathrm{H}$ : low/high frequency

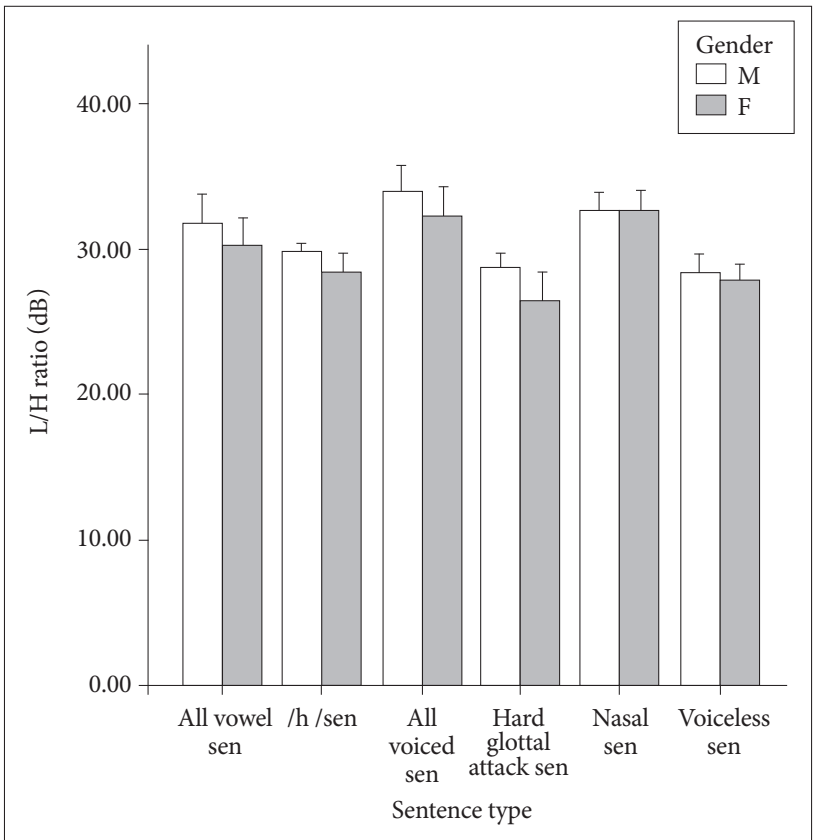

Figure 11. Comparison of $\mathrm{L} / \mathrm{H}$ ratio measures according to gender and sentence type. L/H: low/high frequency, sen: sentence.
고, /히으로 시작하는 문장, 비음이 포함된 문장 순으로 높았 고, 강한 성대접촉을 유도하는 문장이 가장 낮게 나타났다(Table 3, Figure 11). 혼합 이원배치분산분석(mixed two-way ANOVA) 결과, 성별과 문장 유형 간에는 상호작용은 유의미하 지 않았고 $[\mathrm{F}(5,90)=1.353, p=0.250]$, 성별 간 $[\mathrm{F}(1,18)=3.226$, $p=0.089]$ 에는 유의한 차이가 없었으나, 문장 유형 간 $[\mathrm{F}(5,90)=$ 44.258, $p=0.000]$ 통계적으로 유의미한 차이가 나타났다. 대 응별 비교결과, 단모음이 모두 포함된 문장은/히으로 시작하 는 문장 $(p=0.003)$, 모든 단모음이 포함된 문장 $(p=0.003)$, 모 두 유성음으로 된 문장 $(p=0.000)$, 강한 성대접촉을 유도하는 문장 $(p=0.000)$, 비음이 포함된 문장 $(p=0.014)$, 무성파열음이 가중된 문장 $(p=0.000)$ 과 차이를 보였고, /히으로 시작하는 문장은 모든 단모음이 포함된 문장 $(p=0.003)$, 모두 유성음으 로 된 문장 $(p=0.000)$, 강한 성대접촉을 유도하는 문장 $(p=$ $0.000)$, 비음이 포함된 문장 $(p=0.000)$, 무성파열음이 가중된 문장 $(p=0.041)$ 과 유의한 차이를 보였다. 한편, 모두 유성음으 로 된 문장은 비음을 포함한 문장과만 유의한 차이를 보이지 않았으며 $(p=0.305)$ 모든 단모음이 포함된 문장 $(p=0.003), /$ 히 으로 시작하는 문장 $(p=0.000)$, 강한 성대접촉을 유도하는 문 장 $(p=0.000)$, 무성파열음이 강조된 문장 $(p=0.000)$ 과 유의한 차이를 보였다. 강한 성대접촉을 유도하는 문장은 모든 단모음 이 포함된 문장 $(p=0.000), /$ 히으로 시작하는 문장 $(p=0.000)$, 모두 유성음으로 된 문장 $(p=0.000)$, 비음이 포함된 문장 $(p=$ 0.000)과 유의한 차이를 보였다.

비음이 포함된 문장은 모든 단모음을 포함하는 문장 $(p=$ $0.014), /$ 히으로 시작하는 문장 $(p=0.000)$, 강한 성대접촉을 유 도하는 문장 $(p=0.000)$, 무성파열음이 강조된 문장 $(p=0.000)$ 과 차이를 보였고, 무성파열음이 가중된 문장은 모든 모음을 포함하는 문장 $(p=0.000), /$ 흐으로 시작하는 문장 $(p=0.044)$, 모두 유성음으로 된 문장 $(p=0.000)$, 비음이 포함된 문장 $(p=$ 0.000)과 유의한 차이를 보였다.

\section{DISCUSSIONS}

국내 임상 현장에서 청지각적 평가는 국외와 마찬가지로 모 든 음성 평가방법 중에서 언어재활사가 가장 많이 사용하는 평 가 방법이다(Choi, 2013; Oates, 2009). 연결발화를 이용한 청 지각적 평가는 일상생활에서 음성장애에 문제를 보이는 환자 들의 음질을 측정하는 데 매우 유용한 검사이므로 국내에서도 음성장애의 다양한 생리적 특성을 반영할 수 있는 음질 평가 를 위한 표준화된 말과제들이 요구되어 왔다. 이에 본 연구에서 는 음성장애 환자의 청지각적 음질 평가를 위해 연결발화 수준 에서 다양한 후두의 움직임에 따른 표준문장을 개발하고 타당 
도를 검증하고자 하였다. 표준문장 개발에 앞서, 현재 가장 많 이 사용되는 표준문단의 음소 빈도 및 분포와 단어 빈도를 조 사하였고, 공적 대화(상담, 토론, 회의, 구매 대화, 진료 대화, TV나 라디오 방송 대화, 중계) 및 사적 대화(일상 대화, 주제 대화, 수업 대화)와 공적 독백(강의, 강연, 발표, 설교, 식사)과 사적 독백(경험담 말하기, 줄거리 말하기, 동화구연)을 통해 얻 어진 세종 구어 말뭉치에 나타난 우리나라 성인의 구어 어휘의 빈도를 조사하여 문장을 개발하였다.

우리나라 표준문단을 분석한 결과, 두 표준문단 모두 한국 어 단모음 7개////, / / /, / //, / I/, / T//, / //, / //)를 모두 포함하 였다. 음소 빈도별로 볼 때 '가을' 문단은 자음 $56 \%$, 모음 $44 \%$ 였고, '산책' 문단도 자음 59\%, 모음 $41 \%$ 로 자음 빈도가 더 높 게 나타났다. 가장 높은 음소 빈도를 보인 것은 두 표준문단 모 두 모음 / / / 였다. '가을' 문단은/F/, /ㄹ/, /ㄴ/, / ㄷ/, / ㄱ/, / / / 순이 었고, '산책' 문단은 / / / 다음에 /ㄴ/, /ㄹ/, ///, / ㄱ/, / / / 순으로 공명음 /ㄴ/과 /리이 가장 많았고 / ᄀ / 이 그 뒤를 이었다. 표준 어에 가까운 방언을 구사하는 20대 성인 자유발화를 분석한 $\operatorname{Shin}$ (2008)의 연구에서도 가장 높은 빈도를 보인 음소는 / / / 였 고, 이어서 /ㄴ/, / //, /ㄹ/, / //, / _ / 순으로 두 개의 표준문단과 유 사한 음소 분포를 보였다. 자음 빈도를 보면, '가을 문단은 /ㄹ/ 이 18\%(83/468)로 가장 많았고, /ㄴ/, /ㄷ/, / ㄱ/, /ㅁ/, /ㅅ/, /ㅎ/, /ㅈ/, /ㅊ/, /피, /E/ 순으로 비음과 유음이 높은 비율을 차지하 였고, 무성파열음 /피/, /E/ 빈도가 낮았다. '산책' 문단은 전체 자 음 중 비음 ''이 23\%(106/471)로 가장 높은 비율을 차지하였고, /ㄹ/, /ᄀᄀ/, /ㄷ/, /ㅁ/, /ㅂ/, /ㅈ/, /O/, /匹/, /ネ/, /ㅎ/, / El, /T//, /피, /ㅆ/, /삐, /ㅉ/ 순으로 비음과 유음의 비율의 출현율이 높았고, 무성파열음의 비중이 낮게 나타났다. Shin(2008)의 연구에서 도 자음 중 가장 빈도가 높은 음소는 /ㄴ/이었으며, / ᄀ / / / ㄹ/, /ㅁ/, /ㄷ/, /ㅈ/, / / / 순으로 표준문단의 자음 빈도와 비슷한 분 포를 보였다.

음절 내 위치로 볼 때, 두 문단 모두 초성이 종성에 비해 높 은 빈도를 보였다. '가을' 문단에서는 자음 중 $75 \%$ 가 초성으로 사용되었고, $25 \%$ 가 종성으로 사용된 반면, '산책' 문단에서는 자음 중 $62 \%$ 가 초성, $38 \%$ 가 종성으로 사용되어 두 문단이 자 음이 비슷한 음절 위치 분포를 보였다. 초성 중에서는 '가을' 문 단은 /ᄀᄀ/이 가장 많았으며, 산책' 문단은 /ㄴ/이 가장 높은 빈도 를 보였다. '가을' 문단은 /ㄱ/, /ㄹ/, /ㄷ/, /ㄴ/, /ㅎ/, /ㅅ/, /ㅁ/, /ㅂ/, / ㄸ/, /ㅊ/, /E/, /피, /E/, /삐/, /ㅉ/ 순이었고, '산책' 문단은 /ㄴ/, /ㄹ/, /ᄀᄀ/, /ㅅ/, /ㅁ/, /ㅈ/, /ㄷ/, /ㅂ/, /ㄸ/, /ㅊ/, /ㅌ/, / ㄲ/, /ㅆ/, /ㅂ/, /ㅉ/ 순이었다. 초성의 자음 빈도로 보았을 때, 두 문단 모두 / ᄀ/, /ㄴ/, /ㄷ/, /리이 전체 초성 출현 빈도의 절반 이상을 차지하였 다. Shin(2008)의 연구에서도 초성 중 / ᄀ/이 가장 높은 빈도를 보였고, 가장 낮은 빈도는 /빠/이었다.
종성 위치에서는 7종성 원칙에 입각하여 '가을' 문단은 7개 자음 중 /ㄴ/이 가장 많았고, /ㄹ/, / 이순으로 공명음의 출현 빈 도가 높았으며, 마찬가지로 '산책' 문단에서도 /ㄴ/이 압도적으로 많았고, /ㄹ/, / / / 순으로 공명음 비율이 매우 높아 두 표준문단 의 종성에서의 자음 빈도는 유사한 분포를 보였다. Shin(2008) 의 성인 자유발화 분석에서도 종성 자음은 /ㄴ/이 가장 많았 고, /O/, /리 순으로 두 표준문단과 균등한 분포를 보였다.

조음방법별로는 표준문단 모두 파열음의 비중이 가장 많았 으며, 비음, 마찰음, 파찰음, 유음 순으로 Shin(2008)의 연구와 비슷한 분포를 보였다. 조음 위치별로는 두 문단 모두 치경음이 압도적으로 많았고 연구개음, 양순음, 경구개음, 성문음 순이었 다. 이러한 빈도 분포는 우리나라의 19 개 자음 중 치경음이 가 장 빈도가 많은 음소를 포함하는 것과 연관이 있을 것이다.

발성 유형별로는 표준문단 모두 평음이 압도적으로 높은 빈 도를 보였으며, 경음이 가장 낮은 빈도를 보였다.

단어 빈도에서는 '가을' 문단은 '하다'가 6회로 가장 많았고, 조사를 제외하면 '가을이 5 회로 가장 많았다. 반면, '산책' 문단 은 ‘아이'가 13회로 가장 많았으며, 조사를 제외하면 '있다' 5 회, '길' 5 회로 가장 많았다. '하다'는 성인 구어 말뭉치에서 가장 높 은 빈도를 나타낸 단어였으며, '에', '가, '는, '이', '고', '을, '를'과 같은 조사가 높은 빈도를 나타내었고, '이다'와 '있다'는 동사로 는 두 번째로 높은 빈도를 보였다.

개발된 표준문장 중 한국어 모든 단모음이 포함된 문장은 '친구한테 가면서 꼭 전화를 한다'였는데 음소 빈도를 살펴보 면, 모든 7개 단모음이 포함되어 있으며, '한다'는 성인 구어 말 뭉치에서 총 33,701단어 중 가장 빈도가 높은 단어였고, '를' 12 위, '면서'는 총 117위, '한테'는 156위, '친구' 192위, '전화' 294위, ‘꼭’은 404위로 높은 빈도에 속하였다. 또한 모음 빈도도 모든 모음이 다 포함되었지만, 모음 중 / / / 빈도가 가장 높았고, 자 음 빈도는 'ㄴㅣㅣ 가장 높았고, 'ㄱ' ‘'순운으로 표준문단과 유사 한 분포를 보였다. /히으로 시작하는 부드러운 발성을 강조하 는 문장 '하루에 한 번 할인 행사를 한다'는 'ㅎ'으로 시작된 고 빈도 단어 목록 중 모음 중에서는 / / / 모음이 가장 빈도가 높 고, 자음 빈도는 'ㅎ'이 가장 많이 포함되도록 구성하였다. 또한 단어 빈도는 구어 말뭉치에서 '하루’는 645위, '한다' 1 위, '한 번' 196위, '할인' 3,556위, ‘행사' 2,297위로 빈도가 높은 단어 중에 서 선정하였다.

모든 유성음으로 된 문장은 모음으로 시작하는 고빈도 단어 중 선택하여 문장을 개발하였으며, 모음과 공명음으로 된 음소 로 이루어졌다. '어린이'는 3,811위, '5월은 1,751위로 높은 빈도 에 속하였다. 강한 성대접촉을 유도하는 문장은 모음으로 시작 하는 고빈도 단어 목록 중 1 음절에 강세가 되도록 들어가는 모 음을 포함하는 단어 중에서 단어를 선정하여 문장을 개발하였 
다. 음소 빈도 역시 모음 중 / / / 가 가장 높았고, / / 순이었다. '이'는 88위, '앞'은 315위, '아이' 486위, '앉다' 554위, '있다' 96위 로 고빈도 단어에 속하였다. 비음이 포함된 문장 '매일 운동하 고 물을 많이 마신다는 비음이 포함된 고빈도 단어 목록 중 단 어를 선정하였으며, 자음 중 비음이 많이 포함되도록 하였다. '매일은 1,921위, ‘운동' 2,657위, '많이' 104위, '마시다' 630위였 다. 마지막으로 무성파열음이 가중된 문장 '커피가 튄 파카를 털었다는 자음 음소 중 무성파열음이 많이 포함된 단어를 포 함하여 문장을 개발하였다. 모음 빈도는 역시 / / / 모음이 가장 높았으며, 무성파열음 중 고빈도 단어 목록 내 단어를 선정하 였다. '커피'가 2,763위, '튀다'가 2,139위, '파카'가 3,732위로 주 로 무성파열음은 전체 구어 말뭉치에서도 전체 고빈도 단어 중 후순위에 포함되어 있는 것이 많았지만, 선정된 어휘는 무성파 열음 중에서는 고빈도를 나타내는 어휘에 속하였다. 따라서, 모 든 문장은 실제 일상생활의 성인 자유발화 빈도에서 나타나는 단어나 음소 빈도를 고려하였으며, 표준문단의 음소 빈도를 고 려하여 음소 구성 빈도의 균형을 맞추었다.

또한 개발된 문장의 타당도를 조사하기 위하여 정상 성인을 대상으로 연결발화를 측정할 수 있는 음향학적 분석을 이용하 여 각 문장 간 주파수 및 캡스트럼 분석을 실시하였다. 특히 캡 스트럼 분석은 음질을 분석하기 위해서 기존의 모음 연장발성 을 분석해 온 제한적인 음향학적 분석의 대안으로 연결발화를 분석할 수 있는 음향학적 측정 방법이고(Yu et al., 2017). 그중 $\mathrm{CPP}$ 는 청지각적 음질 평가와 상관성이 높다고 보고되었다(Choi \& Choi, 2016; Lowell, 2012). 본 연구에서 문장 유형 간 차이를 살펴본 결과, $\mathrm{CPP}$ 문장 간 유의한 차이를 보였는데, 가장 높은 문장은 모두 유성음으로 된 문장이었고, 무성파열음이 가중된 문장이 가장 낮았다. 무성파열음 산출 동안은 성대가 열려 있고 유성음을 산출하는 동안에 성대가 진동하므로, 문장의 모든 음 소가 유성음인 경우는 가장 $\mathrm{CPP}$ 가 높으며, 성대가 가장 주기적 으로 진동하는 것을 알 수 있다. Choi \& Choi(2017)의 연구에서 는 자음이 음질에 미치는 영향을 캡스트럼 분석을 통하여 살 펴보았는데, 파열음 반복 문장이 마찰음과 파찰음의 성격을 동 시에 가진 파찰음 반복 문장보다 낮은 $\mathrm{CPP}$ 값을 보였으며, 반 면 비음과 유음은 성대를 진동시키는 공명음으로서 가장 높은 $\mathrm{CPP}$ 값을 보여 본 연구결과와 유사하였다.

$\mathrm{L} / \mathrm{H}$ ratio는 $4,000 \mathrm{~Hz}$ 를 기준으로 $4,000 \mathrm{~Hz}$ 위아래의 평균 에너지 비율을 의미하는데, 고주파수의 에너지가 작을수록 L/ $\mathrm{H}$ ratio 값은 커지게 된다. 본 연구에서 강한 성대접촉을 유도 하는 문장 '이 앞에 아이가 앉아 있다'와 파열음이 가중된 문장 인 '커피가 튄 파카를 털었다'에서 낮게 나타나고 모두 유성음 으로 된 문장에서 가장 높게 나타났는데, /ㄷ/, /ㄸ/, /E/와 같은 파열음이 가중된 문장일수록 $4,000 \mathrm{~Hz}$ 이상 고주파수의 특성
을 가지므로 $\mathrm{L} / \mathrm{H}$ ratio가 작게 나타나고, 반면에 모두 유성음 으로 이루어진 문장은 모음과 공명자음으로 이루어져 있으므 로 높은 $\mathrm{L} / \mathrm{H}$ ratio 값을 보일 것이다.

마지막으로, 발화 기본주파수에서는 무성파열음이 가중된 문장이 가장 유의하게 높았으며, 모두 유성음으로 된 문장이 가 장 낮게 나타났다. 한국어 유의미 단음절의 초, 중, 종성 주파수 를 분석한 결과, 비음과 유음인 /ㄴ/, /ㄹ/, /ㅁㅇㅢ 평균주파수는 초성에서 $500 \mathrm{~Hz}$ 이하의 저주파수 영역을 나타내는 음소로 나 타났으며, / ㄱ/, /T//, /ㅂ/, /삐/, /ㅇ/, /ㅋ//, /피/, /ㅎ/은 약 1,000 2,500 Hz, /ㄷ/, /匹/, /ㅈ/, / / /, / //, / ㅌ/는 약 4,000 5,000 Hz, /시, /씨은 약 5,000 6,000 Hz 영역의 주파수 특성을 갖는 음 소로 나타났고, 종성에서는 /ᄀᄀ/, /ㄴ/, /ㄷ/, /ㄹ/, /ㅁ/, /ㅂ/, /이이 모두 비교적 일관되게 2,000 3,000 Hz 사이의 중주파수 특성 을 나타내었다(Kim et al., 2013). 따라서 무성파열음이 가중된 문장에서는 / $/ \exists /, / E /, /$ 표/과 같은 음소가 포함되었는데 이러한 음소가 고주파수 특성을 나타내어 높은 발화주파수를 나타낸 것으로 보인 반면, 본 연구에서 개발된 유성음으로만 된 문장 은 모음과 유음과 비음을 포함하는 저주파수 특성을 나타내므 로 표준문장의 발화 기본주파수에도 영향을 미친 것으로 보인 다. Sandage et al.(2015)의 연구에서도 연속발화의 문장에 따 라 기본주파수의 차이를 보였는데 이러한 차이는 서로 다른 자 음 음소 문맥이 발화 기본주파수에 영향을 준 것으로 보인다.

본 연구는 한국 표준문단의 음소 빈도를 분석하고, '세종' 구 어 말뭉치와 한국인 성인 자유발화를 기초로 하여 연속발화에 서 다양한 음소 문맥을 강조한 표준문장을 개발하고 타당도를 검토하였다. 본 연구에서 개발된 문장은 한국어 표준문단으로 많이 사용되고 있는 '가을'과 '산책'의 문장 분석을 통해 음소와 단어를 배치하고 기존 문단의 음소 빈도, 음소적 분포의 균형, 빈도 높은 단어의 배치, 음절 수 조정, 문장 길이의 조정을 거쳐 개발되었다. 추후의 연구에서는 음성장애 환자들을 대상으로 개발된 표준문장을 이용하여 청지각적 평가와 음향학적 평가 를 병행하여 살펴보는 것이 필요하다. 이 연구의 결과를 통해 표준문장이 음성 평가 시 다양한 후두 움직임의 해부학적, 생 리학적 임상적 정보를 제공하여 주는 데 유용하게 사용되기를 기대한다.

중심 단어 : 자음·모음·연결발화·음질.

\section{Acknowledgments}

본 연구는 2013년도 정부(교육원)의 재원으로 한국연구재단의 지 원을 받아 연구되었음(NRF-2013 S1A5A8024543).

\section{REFERENCES}

Choi, S. H. (2013). Speech-language pathologists' voice assessment and voice therapy practices: A survey for standard clinical guideline and 
evidence-based practice. Communication Sciences and Disorders, 18(4), 473-485.

Choi, S. H. \& Choi, C. C. (2017). Proceedings from the 2017 Spring Conference of the Korean Society of Speech Science: Consonant Effects on Vocal Quality: Cepstral and Spectral Analysis. Cheonan, Chungnam; Korea Nazarene University.

Choi, S. H. \& Choi, C. H. (2016). The effect of gender and speech task on cepstral and spectral-measures of Korean normal speakers. Audiology and Speech Research, 12(3), 157-163.

Colton, R. H., Paseman, A., Kelley, R. T., Stepp, D., \& Casper, J. K. (2011). Spectral moment analysis of unilateral vocal fold paralysis. Journal of Voice, 25(3), 330-336.

Jeong, O. R. (1994). Daegu Diagnostic Aphasia Examination. Seoul: Sigmapress.

Kempster, G. B., Gerratt, B. R., Verdolini Abbott, K., Barkmeier-Kraemer, J., \& Hillman, R. E. (2009). Consensus auditory-perceptual evaluation of voice: Development of a standardized clinical protocol. American Journal of Speech-Language Pathology, 18(2), 124-132.

Kim, H. H. (1996). Proceedings on the 2nd conference in the Korean Society of Phonetic Sciences and Speech Technology Semiannual: Perceptual, Acoustical, Physiological Tools in Ataxic Dysarthria Management: A Case Study. Seoul.

Kim, J. S., Shin, E. Y., \& Cho, E. B. (2013). A Study on initial, middle, final phoneme frequency analyses of the Korean meaningful monosyllabic words. Audiology and Speech Research, 9(2), 127-136.

Kreiman, J., Gerratt, B. R., Kempster, G. B., Erman, A., \& Berke, G. S. (1993). Perceptual evaluation of voice quality: Review, tutorial, and a framework for future research. Journal of Speech and Hearing Research, 36(1), 2140.

Lee, S. J., Lim, S. E., \& Choi, H. S. (2017). A comparison of cepstral and spectral measures according to measurement position in a reading passage. Communication Sciences and Disorders, 22(4), 818-826.

Lowell, S. Y., Kelley, R. T., Awan, S. N., Colton, R. H., \& Chan, N. H. (2012). Spectral- and cepstral-based acoustic features of dysphonic, strained voice quality. The Annals of Otology, Rhinology, and Laryngology, 121(8), 539-548.

Lu, F. L. \& Matteson, S. (2014). Speech tasks and interrater reliability in perceptual voice evaluation. Journal of Voice, 28(6), 725-732.
Mozzanica, F., Ginocchio, D., Borghi, E., Bachmann, C., \& Schindler, A. (2013). Reliability and validity of the Italian version of the Consensus Auditory-Perceptual Evaluation of Voice (CAPE-V). Folia Phoniatrica et Logopaedica, 65(5), 257-265.

Núñez-Batalla, F., Morato-Galán, M., García-López, I., \& Ávila-Menéndez, A. (2015). Validation of the Spanish adaptation of the Consensus Auditory-Perceptual Evaluation of Voice (CAPE-V). Acta Otorrinolaringologica Española, 66(5), 249-257.

Oates, J. (2009). Auditory-perceptual evaluation of disordered voice quality: Pros, cons and future directions. Folia Phoniatrica et Logopaedica, 61(1), 49-56.

Parsa, V. \& Jamieson, D. G. (2001). Acoustic discrimination of pathological voice: Sustained vowels versus continuous speech. Journal of Speech, Language, and Hearing Research, 44(2), 327-339.

Pyo, H., Kim, S., \& Baek, S. (2014). A comparison study of breath groups during reading paragraph tasks in normal adults and adult patients with voice disorders: A preliminary study. Phonetics and Speech Sciences, 6(4), 181-187.

Sandage, M. J., Plexico, L. W., \& Schiwitz, A. (2015). Clinical utility of CAPE$\mathrm{V}$ sentences for determination of speaking fundamental frequency. Journal of Voice, 29(4), 441-445.

Seo, S. K. (2015). Korean Speech Frequency Dictionary. Seoul: Hankukmunhwasa.

Shin, J. (2008). Phoneme and syllable frequencies of Korean based on the analysis of spontaneous speech data. Communication Sciences and Disorders, 13(2), 193-215.

Shin, J. Y. \& Cha, J. E. (2003). The System of Korean Sounds. (1st ed.). Seoul: Hankukmunhwasa.

Sohn, J. H. (2008). GRBAS and voice handicap index. Journal of the Korean Society of Laryngology, Phoniatrics, and Logopedics, 19(2), 89-95.

Yu, M., Choi, S.H., Choi, C. H., \& Lee, K (2017). Usefulness of cepstral acoustic index for estimating objective dysphonia severity. Communication Sciences and Disorders, 22(3), 587-596.

Zraick, R. I., Kempster, G. B., Connor, N. P., Thibeault, S., Klaben, B. K., Bursac, Z., et al. (2011). Establishing validity of the Consensus AuditoryPerceptual Evaluation of Voice (CAPE-V). American Journal of SpeechLanguage Pathology, 20(1), 14-22. 
APPENDICES

Appendix 1. Word frequency in 'Fall' passage

\begin{tabular}{|c|c|c|c|c|c|c|c|c|c|c|c|}
\hline 단어 & 빈도 & 단어 & 빈도 & 단어 & 빈도 & 단어 & 빈도 & 단어 & 빈도 & 단어 & 빈도 \\
\hline 우리나라 & 1 & 무엇 & 1 & 아름답다 & 3 & 오르다 & 2 & 참으로 & 1 & 의 & 6 \\
\hline 가을 & 5 & 그 & 1 & 빼어나다 & 1 & 느끼다 & 1 & 더욱 & 1 & 은/는 & 5 \\
\hline 산 & 1 & 이것 & 1 & 듯하다 & 4 & 쓰다듬다 & 1 & 더 & 1 & 보다 & 1 \\
\hline 때 & 1 & 이다 & 1 & 완만하다 & 1 & 깎다 & 1 & 절로 & 1 & 도 & 5 \\
\hline 산등성이 & 1 & 천고마비 & 1 & 뾰족하다 & 1 & 놓다 & 2 & 쌍쌍이 & 1 & 에 & 6 \\
\hline 감탄 & 1 & 계절 & 3 & 여러 & 2 & 어우러지다 & 1 & 라면 & 1 & 을/를 & 13 \\
\hline 수 & 2 & 이유 & 1 & 신비롭다 & 1 & 따르다 & 1 & 과연 & 1 & 이 & 3 \\
\hline 색 & 3 & 예 & 1 & 희다 & 1 & 보다 & 1 & 또한 & 1 & 과 & 1 \\
\hline 님 & 1 & 구름 & 1 & 높다 & 1 & 금하다 & 1 & 하여 & 1 & 가 & 1 \\
\hline 잠기다 & 1 & 짝 & 1 & 파랗다 & 1 & 없다 & 1 & 시시때때로 & 1 & 들 & 4 \\
\hline 등 & 2 & 하늘 & 2 & 같다 & 1 & 되다 & 2 & 작다 & 1 & 까지 & 1 \\
\hline 가지 & 2 & 숲 & 1 & 풍성하다 & 1 & 어우러지다 & 1 & 대표적 & 1 & 서 & 1 \\
\hline 색깔 & 1 & 속 & 1 & 아니다 & 1 & 타다 & 1 & 붉은 & 1 & 부터 & 1 \\
\hline 감동 & 1 & 노란 & 1 & 크다 & 1 & 주다 & 2 & 푸른 & 1 & 이라(고) & 3 \\
\hline 하다 & 6 & 눕다 & 1 & 바라보다 & 2 & 나아가다 & 1 & 노란 & 1 & 뿐 & 1 \\
\hline 짓다 & 1 & 있다 & 1 & 쳐다보다 & 1 & 일컫다 & 1 & 알다 & 1 & 만 & 2 \\
\hline 것 & 1 & 만 & 1 & 오곡백과 & 1 & 먹거리 & 1 & 때문 & 1 & 께/에게 & 2 \\
\hline 결실 & 1 & 햅쌀 & 1 & 밤 & 1 & 호두 & 1 & 대추 & 1 & 떡 & 1 \\
\hline 과일 & 1 & 명절 & 1 & 추석 & 1 & 조상 & 1 & 차례 & 1 & 독서 & 1 \\
\hline 책 & 1 & 명상 & 1 & 마음 & 1 & 힘 & 1 & 맛보다 & 1 & 쌓다 & 1 \\
\hline 지내다 & 1 & 읽다 & 1 & 살찌우다 & 1 & & & & & & \\
\hline
\end{tabular}


Development of Korean Sentences for Perceptual Voice Evaluation

Appendix 2. Word frequency in 'Walk' passage

\begin{tabular}{|c|c|c|c|c|c|c|c|c|c|c|c|}
\hline 단어 & 빈도 & 단어 & 빈도 & 단어 & 빈도 & 단어 & 빈도 & 단어 & 빈도 & 단어 & 빈도 \\
\hline 산 & 1 & 내 & 1 & 높은 & 1 & 마시며 & 1 & 활짝 & 1 & 은/는 & 28 \\
\hline 공기 & 1 & 아저씨 & 1 & 넓게 & 1 & 지르며 & 1 & 쭉쭉 & 1 & 에 & 8 \\
\hline 소리 & 2 & 아주머니 & 1 & 길게 & 1 & 올라가 & 1 & 동동 & 1 & 이/가 & 10 \\
\hline 가슴 & 1 & 그네 & 1 & 뻗어 & 2 & 열리는 & 1 & 랄랄랄 & 1 & 을/를 & 13 \\
\hline 바닷가 & 1 & 술래잡기 & 1 & 곧은 & 1 & 펼쳐 & 1 & 너무 & 1 & 으로 & 2 \\
\hline 조개 & 1 & 미끄럼 & 1 & 우는 & 1 & 바라보면 & 1 & 쌩쌩 & 1 & 처럼 & 2 \\
\hline 바다 & 1 & 부르는 & 1 & 웃는 & 1 & 걸어가면서 & 1 & 통 & 1 & 며 & 4 \\
\hline 마음 & 2 & 소리 & 1 & 다친 & 1 & 반듯하게 & 1 & 파는 & 1 & 도 & 1 \\
\hline 가로수 & 1 & 미끄럼 & 1 & 벗겨진 & 1 & 놓은 & 2 & 부르는 & 1 & 비디오 & 1 \\
\hline 길 & 5 & 지나다니며 & 1 & 비좁다 & 1 & 살아야곘다 & 1 & 있는 & 5 & 채소 & 1 \\
\hline 나무 & 1 & 시장 & 2 & 늘어선 & 1 & 가면 & 2 & 물건 & 1 & 옷집 & 1 \\
\hline 자연 & 1 & 구경거리 & 1 & 차려진 & 1 & 타는 & 2 & 오디오 & 1 & 업소 & 1 \\
\hline 생각 & 2 & 액세서리 & 1 & 아슬한 & 1 & 다니는 & 1 & 가구점 & 1 & 차 & 1 \\
\hline 아이 & 13 & 구르는 & 1 & 발 & 1 & 하는 & 2 & 식당 & 1 & 운전 & 1 \\
\hline 놀이터 & 2 & 업소 & 1 & 신발 & 1 & 지르는 & 1 & 시장길 & 1 & 가구점 & 1 \\
\hline 그네 & 1 & 술래잡기 & 1 & 노래 & 1 & 앉은 & 1 & 심정 & 1 & 아파트 & 1 \\
\hline
\end{tabular}

Appendix 3. High-frequency words begins with $/ \mathrm{h} /$ sound in Sejong Corpus

\begin{tabular}{|c|c|c|c|c|c|c|}
\hline 하다 & 형 & 하나 & 회사 & 하루 & 호박 & 흐리다 \\
\hline 한번 & 혹시 & 혼자 & 회의 & 하얗다 & 허락 & 휴대폰 \\
\hline 힘들다 & 후배 & 행사 & 허리 & 학교 & 혹 & 휴지 \\
\hline 학생 & 회원 & 할아버지 & 핸드폰 & 휴가 & 호수 & 흉내 \\
\hline 화장실 & 해외 & 흰색 & 호텔 & 할인 & 확장 & 힘 \\
\hline 행동 & 하여튼 & 행복하다 & 한꺼번에 & 하여튼 & 화내다 & 해수욕장 \\
\hline 환자 & 하늘 & 후배 & 확인하다 & 흐르다 & 향기 & 항구 \\
\hline 흘리다 & 화장품 & 훌륭하다 & 후회하다 & 한복 & 흔들리다 & 환불하다 \\
\hline
\end{tabular}


Appendix 4. High-frequency words with all voiced sounds in Sejong Corpus

\begin{tabular}{|c|c|c|c|c|c|c|}
\hline 우리 & 이런 & 어요 & 오늘 & 알다 & 많이 & 님 \\
\hline 이(관형사) & 일 & 오 & 나라 & 언니 & 날 & 어린이 \\
\hline 여러 & 안 & 아마 & 영어 & 왜 & 마음 & 여름 \\
\hline 엄마 & 어요 & 맨날 & 열 & 머리 & 우유 & 이름 \\
\hline 아니면 & 얼마 & 아이 & 이유 & 위 & 랑 & 아우 \\
\hline 몸 & 영 & 아무리 & 아예 & 어머니 & 요리 & 이미 \\
\hline 남 & 내일 & 나이 & 모양 & 오래 & 안녕 & 와인 \\
\hline 오월 & 아니요 & 어린 & 아무 & 미안 & 요런 & 모임 \\
\hline 원인 & 오르다 & 일요일 & 월요일 & 어른 & 인물 & 미리 \\
\hline
\end{tabular}

Appendix 5. High-frequency words begins with vowel sounds in Sejong Corpus

\begin{tabular}{|c|c|c|c|c|c|c|}
\hline 없다 & 아니다 & 어떻게 & 오다 & 이거 & 우산 & 여행 \\
\hline 이(관형사) & 이제 & 있다 & 앞 & 오빠 & 어제 & 어린이 \\
\hline 어디 & 앉다 & 아이 & 아주 & 언니 & 오전 & 요리 \\
\hline 엄마 & 옷 & 언제 & 아직 & 이번 & 우유 & 음식점 \\
\hline 안 & 읽다 & 여기 & 입다 & 얻다 & 운동 & 역 \\
\hline 약 & 울다 & 아침 & 일어나다 & 얼굴 & 이야기 & 은행 \\
\hline 올라가다 & 알다 & 아줌마 & 어머니 & 오래 & 오락 & 아빠 \\
\hline 어서 & 일 & 어린 & 오후 & 입 & 여자 & 오뎅 \\
\hline 오월 & 오르다 & 어떤 & 아버지 & 아프다 & 이사 & 아들 \\
\hline
\end{tabular}


Development of Korean Sentences for Perceptual Voice Evaluation

Appendix 6. High-frequency words incorporated nasal sounds in Sejong Corpus

\begin{tabular}{|c|c|c|c|c|c|c|}
\hline 나라 & 나 & 나오다 & 매일 & 모르다 & 이모 & 머리 \\
\hline 언니 & 이름 & 라면 & 안경 & 마시다 & 만나다 & 먹다 \\
\hline 엄마 & 운동 & 많이 & 고양이 & 편의점 & 계란 & 만두 \\
\hline 영화 & 물 & 영수증 & 냉면 & 용돈 & 미용실 & 음료 \\
\hline 옛날 & 여행 & 만들다 & 어린이 & 몸무게 & 냉장고 & 말리다 \\
\hline 마음 & 동네 & 노래 & 운전 & 여름 & 냉면 & 놀이공원 \\
\hline 은행 & 병원 & 어머니 & 내용 & 모임 & 운전 & 바나나 \\
\hline 점심 & 마을 & 모임 & 네 & 이메일 & 메뉴 & 나이 \\
\hline
\end{tabular}

Appendix 7. High-frequency words weighted with voiceless plosive sounds in Sejong Corpus

\begin{tabular}{|c|c|c|c|c|c|c|}
\hline 크다 & 택시 & 커피 & 택배 & 붙다 & 바퀴 & 파고들다 \\
\hline 팔다 & 코 & 배고프다 & 타다 & 컵 & 폭탄 & 뜨겁다 \\
\hline 높이다 & 파카 & 컴퓨터 & 파스타 & 튀다 & 벚꽃 & 포도 \\
\hline 피자 & 떡볶이 & 다이어트 & 파인애플 & 립스틱 & 터트리다 & 데이트 \\
\hline 포장 & 바닷가 & 아르바이트 & 파티 & 피다 & 트럭 & 턱 \\
\hline 코끼리 & 파다 & 아파트 & 표시 & 이벤트 & 티켓 & 풀 \\
\hline 퍼붓다 & 꼽다 & 포크 & 파도 & 벨트 & 소파 & 투표 \\
\hline 퍼뜨리다 & 디저트 & 카페 & 다투다 & 투피스 & 풍선 & 포테이토 \\
\hline
\end{tabular}

\section{Appendix 8. Standardized sentences}

\begin{tabular}{lll}
\hline 1 & 모든 한국어 단모음이 포함된 문장 & 친구한테 가면서 꼭 전화를 한다. \\
2 & '흐으로 시작되는 문장 & 하루에 한 번 할인 행사를 한다. \\
3 & 모두 유성음으로 된 문장 & 5월 5일은 어린이날이에요. \\
4 & 강한 성대접촉을 유도하는 문장 & 이 앞에 아이가 앉아 있다. \\
5 & 비음이 포함된 문장 & 매일 운동하고 물을 많이 마신다. \\
6 & 무성파열음이 가중된 문장 & 커피가 튄 파카를 털었다. \\
\hline
\end{tabular}

